\title{
高安動脈炎における脳血行再建術後合併症についての検討
}

\author{
吉田 和道, 宮本豙, 野崎 和彦 \\ 永田泉, 菊池 晴彦, 橋本 信夫
}

\section{Retrospective Analysis of Postoperative Complications after Cerebrovascular Reconstruction in Takayasu Arteritis}

Kazumichi Yoshida, M.D., Susumu MrYamoto, M.D., Kazuhiko NozakI, M.D., Izumi Nagata, M.D.,* Haruhiko Kikuchi, M.D.,* and Nobuo HaShimoto, M.D.

Department of Neurosurgery, Kyoto University Graduate School of Medicine, Kyoto, and *National Cardiovascular Center, Osaka, Japan

Summary: As Takayasu arteritis is a systemic disease with considerable operative risks, strict surgical indication and adequate measures against possible postoperative complications are mandatory. Seventeen patients with Takayasu arteritis (3 males and 14 females aged between 13 and 62) were treated since 1984 in our institute. Sixteen bypass surgeries with saphenous vein grafts were performed in 12 patients, 3 bypass surgeries with synthetic grafts were performed in 2 patients and PTA was carried out in 5 patients.

Postoperative hyperperfusion syndrome was observed in 2 patients whose preoperative angiograms had shown the occlusions of the 4 aortic arch branches, and cerebral blood flow (CBF) analysis had revealed diffuse hypoperfusion. Surgical revascularization should be indicated for those patients who have a significant risk of hyperperfusion syndrome.

Sudden cardiac arrest occurred in 2 patients after reconstructive surgery though preoperative examination in cardiac function could not detect any abnormalities.

CBF study is very useful in the treatment of Takayasu arteritis to determine the liklihood of postoperative complications such as hyperperfusion syndrome. In the postoperative period of surgical revascularization, the incidence of unexpectable cardiac complications should be kept in mind.

\section{Key words:}

- Takayasu arteritis

- cerebrovascular reconstruction

- CBF study

- hyperperfusion syndrome

- cardiac failure

Surg Cereb Stroke

(Jpn) 29: 1-8, 2001
はじめに

高安動脈炎は非特異的炎症により大動脈㧍よびその主要 分枝に閉塞性病変を生じる疾患であり，脳虚血症状を伴う 症例に対する種々の血行再建術がこれまでに報告されてい る14) 15).
考慮すると人念な合併症対策が必要とされる，本疾患の脳 血行再建術後に起こりうる合併症として, 急激な脳血流増 加による hyperperfusion syndromeのほかに，全身合併 症のなかでは迅速かつ適切な対応が予後を大きく左右する ものとして心合併症がある.

今回，1）術後 hyperperfusion 出現の予測とその対処法,

本疾患が多臟器病変を伴いうる全身性疾患であることを２）血行再建術後に生じた心合併症に関してその原因と対 京都大学大学院医学研究科 脳神経外科， *国立循噮器病センター(受稿日 1999.8.27)〔連絡先： テ606-8507 京都市左京区晆謨院川原 町 54 京都大学大学院医学研究科 胹神経外科 吉田和道〕 〔Mailing address: Kazumichi YoSHIDA, M.D., Department of Neurosurgery, Kyoto University Graduate School of Medicine, 54 Kawahara-cho, Shogoin, Sakyo-ku, Kyoto, Kyoto 606-8507, Japan] 
Table 1 Summary of the clinical manifestations

\begin{tabular}{|c|c|c|c|}
\hline Case & Age & Sex & Symptoms and signs \\
\hline 1 & 33 & $f$ & visual disturbance \\
\hline 2 & 30 & f & syncope/ visual disturbance \\
\hline 3 & 32 & $f$ & rt. hemiparesis/ aphasia (TIA) \\
\hline 4 & 13 & f & syncope/ visual disturbance \\
\hline 5 & 62 & f & dizziness/ ataxia (VBI) \\
\hline 6 & 34 & $f$ & syncope/ seizure \\
\hline 7 & 38 & f & rt. hemiparesis/ aphasia (stroke) \\
\hline 8 & 40 & $\mathrm{~m}$ & syncope/ visual disturbance \\
\hline 9 & 48 & $f$ & It. hemiparesis (stroke) \\
\hline 10 & 24 & f & free \\
\hline 11 & 26 & f & FUO \\
\hline 12 & 46 & $\mathrm{~m}$ & dysarthria/ shoulder pain \\
\hline 13 & 30 & f & rt. hemiparesis/ aphasia (TIA) \\
\hline 14 & 18 & f & free \\
\hline 15 & 50 & $f$ & syncope/ visual disturbance (TIA) \\
\hline 16 & 40 & $f$ & FUO/ visual disturbance/ shoulder pain \\
\hline 17 & 53 & $\mathrm{~m}$ & shoulder pain \\
\hline
\end{tabular}

Table 2 Classification on angiographical findings and CBF evaluation

\begin{tabular}{ccc}
\hline Group & Angiogram & CBF \\
\hline Group 1 & 4 vessels occluded & diffuse hypoperfusion \\
\hline Group 2 & $\begin{array}{c}\text { Some vessels remain patent } \\
\text { with insufficient intracranial } \\
\text { collaterals }\end{array}$ & hemispheric hypoperfusion \\
\hline Group 3 & $\begin{array}{c}\text { Some vessels remain patent } \\
\text { with sufficient intracranial } \\
\text { collaterals }\end{array}$ & no CBF compromise \\
\hline
\end{tabular}

Table 3 Summary of therapeutic procedures and results

\begin{tabular}{|c|c|c|c|c|}
\hline Case & Group & Treatments & Postop. course & Outcome \\
\hline 1 & N & double SVBG (Ao-rt. MCA \& Ao-lt. VA) & death (aspiration pneumonia) & worsen \\
\hline 2 & G3 & SVBG (Ao-lt. CCA) & uneventful & improved \\
\hline 3 & $\mathrm{~N}$ & SVBG (lt. SA-lt. CCA) & uneventful & improved \\
\hline \multirow[t]{2}{*}{4} & Gl & $\begin{array}{l}\text { double SVBG (Ao-Inno. \& Ao-lt. CCA } \\
\rightarrow \text { delayed occlusion }\end{array}$ & uneventful & improved \\
\hline & & SVBG (SVBG-rt. VA) & hyperperfusion syndrome & improved \\
\hline 5 & G3 & SVBG (Ao-rt. SA) & uneventful & improved \\
\hline 6 & G3 & SVBG (Ao-rt. ICA) & uneventful & improved \\
\hline 7 & G2 & $\begin{array}{l}\text { SVBG (Ao-lt. ICA) } \rightarrow \text { eary graft failure } \\
\text { PTA (It. SA) }\end{array}$ & uneventful & unchanged \\
\hline 8 & Gl & $\begin{array}{l}\text { SVBG (Ao-rt. CCA }) \rightarrow \text { delayed occlusion } \\
\text { SVBG (Ao-rt. CCA }) \rightarrow \text { delayed occlusion } \\
\text { SBG (Ao-bil. CCA })\end{array}$ & $\begin{array}{c}\text { uneventful } \\
\text { hyperperfusion syndrome } \\
\text { hyperperfusion syndrome \& cardiac failure }\end{array}$ & $\begin{array}{l}\text { improved } \\
\text { improved } \\
\text { worsen }\end{array}$ \\
\hline 9 & G2 & $\begin{array}{l}\text { SVBG (Ao-rt. CCA) } \\
\text { PTA (lt. SA \& It. VA) }\end{array}$ & cardiac failure & improved \\
\hline 10 & G3 & PTA (lt. VA) & uneventful & unchanged \\
\hline 11 & G2 & conservative & & unchanged \\
\hline 12 & G3 & conservative & & unchanged \\
\hline 13 & G2 & SBG (Ao-rt. SA \& It. CCA: Y graft) & uneventful & improved \\
\hline 14 & G3 & conservative & & unchanged \\
\hline 15 & G2 & $\begin{array}{l}\text { SBG (rt. SA-rt. CCA) } \\
\text { PTA (rt. VA) }\end{array}$ & uneventful & improved \\
\hline 16 & Gl & $\begin{array}{l}\text { SBG (rt. SA-rt. CCA) } \\
\text { SBG (rt. ECA-lt. CCA) }\end{array}$ & $\begin{array}{l}\text { uneventful } \\
\text { uneventful }\end{array}$ & $\begin{array}{l}\text { improved } \\
\text { improved }\end{array}$ \\
\hline 17 & G3 & PTA (lt. CCA \& bil. SA) & uneventful & improved \\
\hline
\end{tabular}

N: CBF was not evaluated, SBG: synthetic bypass graft, SVBG: saphenous vein bypass graft, Ao: ascending aorta, Inno.: innominate artery, SA: subclavian artery, MCA: middle cerebral artery, CCA: common carotid artery, VA: vertebral artery 

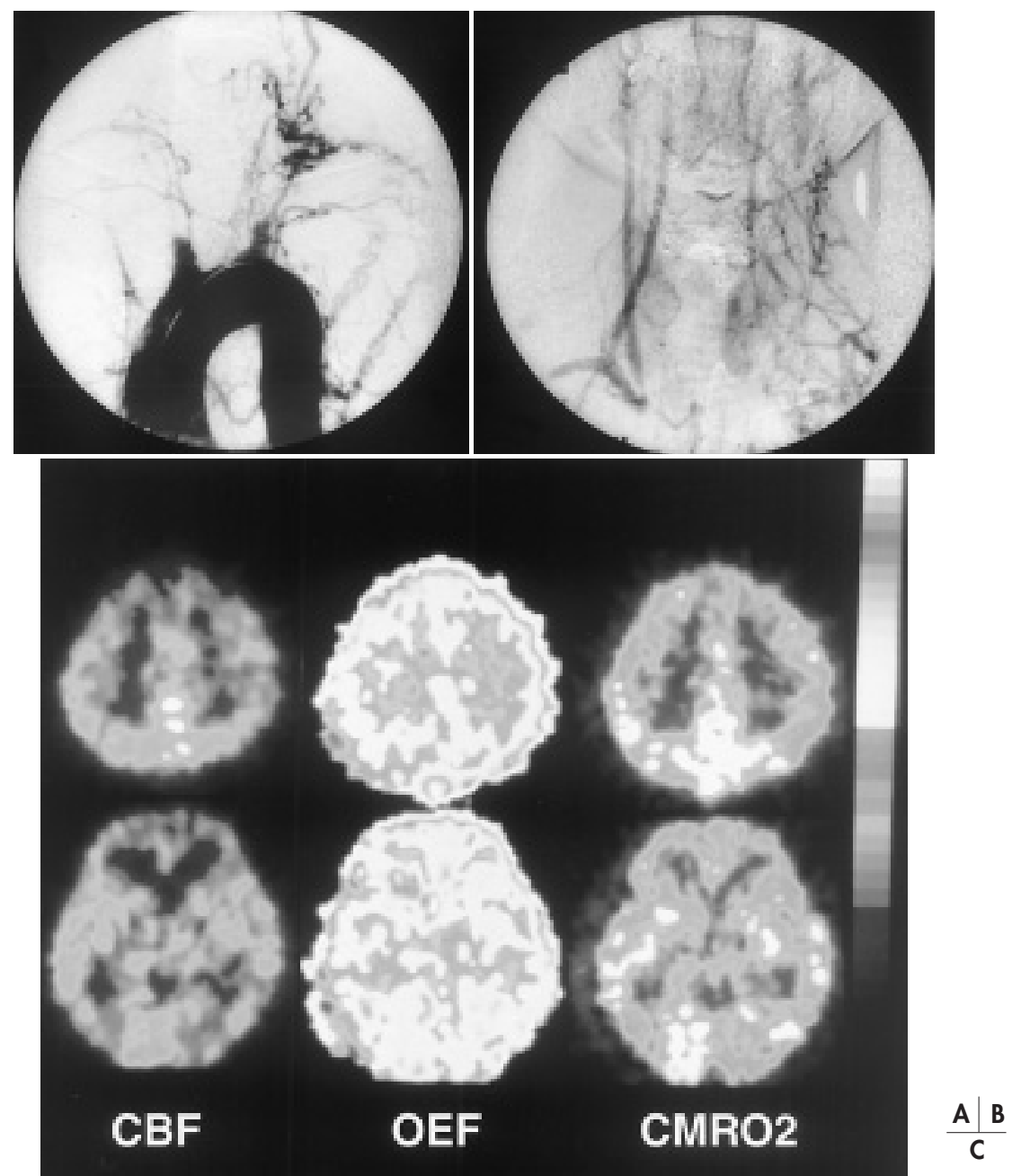

Fig. 1 Aortography and CBF study of group 1 patient (Case 8).

A, B: All of the main branches from ascending aorta were almost occluded.

C: CBF images before bypass surgery.

PET images show diffuse hypoperfusion.

策, 以上の 2 点について, われわれの経験した症例の治療 経過を retrospectiveに検討した。

\section{方 法}

\section{〈症 例〉}

1984年以降当科㧍よび関連施設において診断治療した 高安動脈炎の患者 17 例を対象とした。症例は 13-62 歳(平 均 36 歳), 男性 3 例 (平均 46.3 歳), 女性 14 例 (平均 34.1 歳) であった、その・覧を Table 1 に示した。これらの症例を $\mathrm{CBF}$ 検査の結果と血管撮影の所見に基づいて: つの group に分類した (Table 2).

Gruop 1: 大動脈吻側枝の 4 本 (4 vessels)がすべて䦥塞 して抬り，頭蓋内へはわずかな側副血行を介して血流が供 給されるのみで CBF 検査上 diffuse hypoperfusionとなっ
ている症例.

Group 2: 4 vesselsのうちの・部はpatencyが保たれて いるものの CBF 検査上は hemispheric hypoperfusion 呈 古症例.

Group 3: 4 vesselsのうちの・部は patencyが保たれて おり, CBF 検査上は明らかな異常が認められない症例.

$\mathrm{CBF}$ 検査の種類は, 施行された時期により $\mathrm{Xe}-\mathrm{CT}$, SPECT, PET とさまざまである. Case 1 と 3 に対しては $\mathrm{CBF}$ 検査は施行されなかった。

\section{〈外科的治療〉}

全症例に刘する治療法をTable 3 にまとめた。12例に対

して閉塞血管に対する血行再建術が施行され, そのうち 3 例については合併する狭窄性病変に対し percutaneous 


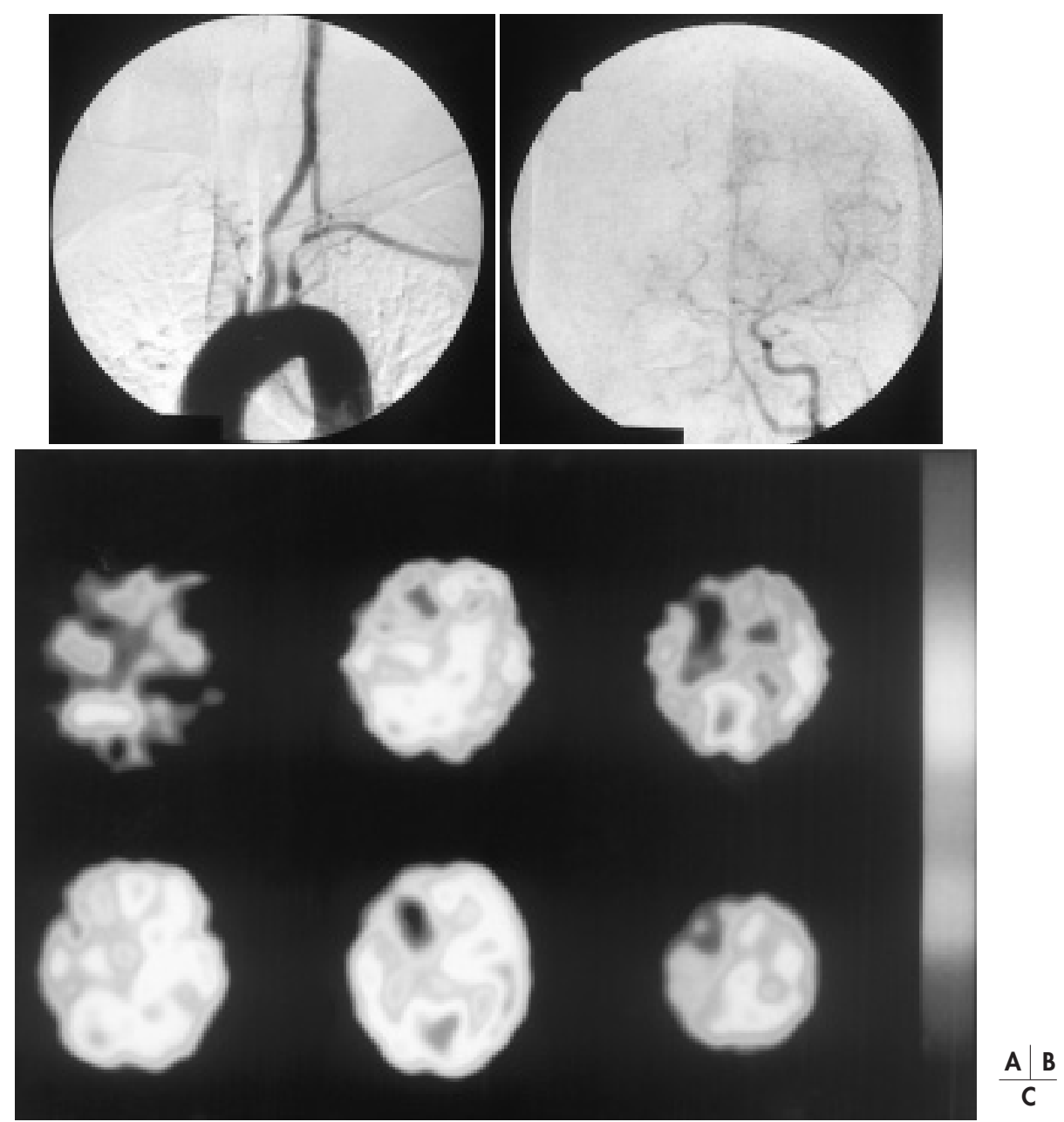

Fig. 2 Aortography and CBF study of group 2 patient (Case 9).

A, B: Aortogram shows occlusion of innominate artery and severe stenosis of left subclavian artery. Collateral blood flow through circle of Willis is insufficient.

C: 99m TC-HM PAO SPECT images reveal a reduction of right hemispheric blood flow.

transluminal angioplasty (PTA)が追加された。他の2 例 に対してはPTAのみが施行された。神経症状が軽度であ るか、まったく認められなかった 3 例については保存的治 療が行われた。

血行再建術としては 9 例において saphenous veinを用 いた胸骨正中切開による上行大動脈－総䁰動脤あるいは上 行大動脈一椎骨動脈間バイパス術が行われた。人工血管を 使用した血行再建は再手術例の1例を含めて計 4 例に施行 された。

\section{結果}

\section{〈臨床症状 (Table 1) 〉}

Group 1 では全例が反復する syncopal attackと著明な 視力障害を認めた。 syncopal attackは収縮期血圧が約
$100 \mathrm{mHg}$ を下回ったさいに出現した。さらに，多くの例 に招いて carotid sinus hy persensitivityのため頸部伸展が 困難であり，前彎姿勢でなければ歩行不能であった。これ らの症状はП常生活に大きな支障となった。CBF 検査は 全般的に高度の hypoperfusion を呈していた（Fig. 1)。

Group 2 では, Case 11 を除く全例で閉塞血管と同侧半 球に脳梗塞を伴って扔り，CBF検査では一側半球の著明 な hypoperfusionを示した。神経症状を認めなかった Case 11 では, CBF 検査上軽度の片侧性 hypoperfusion 示した (Fig. 2).

Group 3 では, 神経症状を欠くものから, 視力障害・症 尜・TIAなど多様な症状を示すものまでさまざまであっ た。Fig. 3 は本 groupに属するCase 2 の血管撮影と CBF

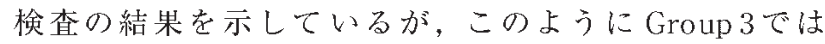



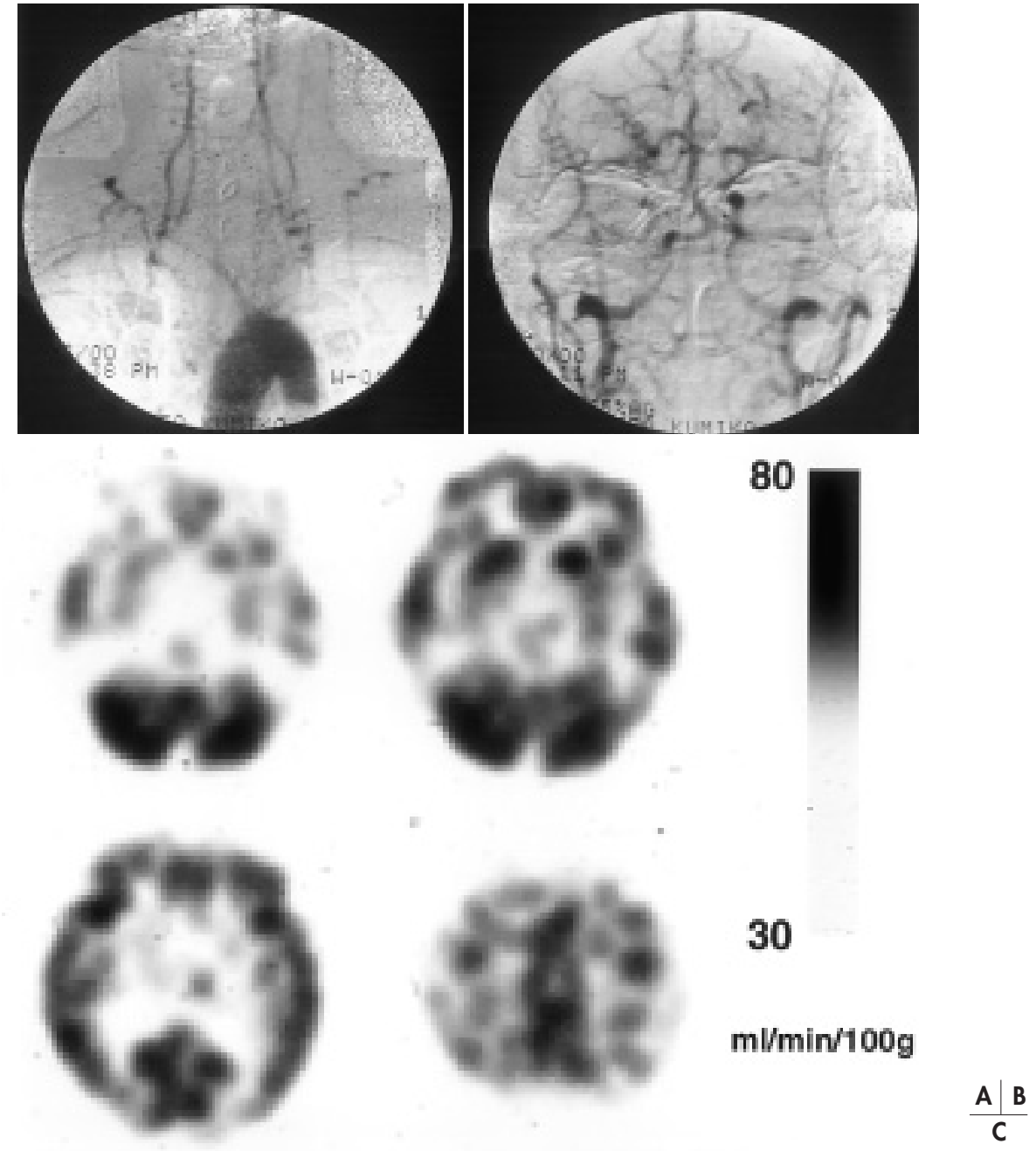

Fig. 3 Aortography and CBF study of group 3 patient (Case 2).
A, B: Only bil. VA are patent and CBF is maintained by sufficient intracra- nial collaterals.
C: $99 \mathrm{~m}$ Tc-HM PAO SPECT lquantitative images of resting state obtained by autoradiographic method) reveals normoperfusion.

$\mathrm{CBF}$ 検査上明らかな脳血流低下を認めなかった。

\section{〈合併症と治療結果 (Table 3) 〉}

再手術例も含めのべ 16 血行再建手術例のうち，3手術 例 (Case 4 and 8)に挄いて術後hyperperfusion syndrome が出現した。これらはいずれも Group 1 患者であった。

術後心機能不全は, 2 例 (Case 8: Group 1 and Case 9: Group 2)において認められた。Case9では, 閉創中にcardiac arrest となったがintraaortic balloon pumping(IABP) と cate cholamine の持続投与によって回復した。

術後合併症として hyperperfusion と cardiac arrestの両 者を伴ったCase 8の治療経過を簡単に紹介する。

Case 8: Fig. 1A, Bは, 初回術前の血管撮影であるが4 vessels は閉塞しておりわずかな側副血行を認めるのみで あった. saphenous veinを用いた上行大動脈一右総橮動脈 バイパスが施行された 20 П後の血管撮影では patencyが 確認された (Fig. 4A). 2 力月後急速な左側視力低下を伴っ たため施行した血管撮影で graft の閉塞が確認され, 再度 saphenous veinによる上行大動脈一右総频動脈バイパスが 施行された。Fig. 5 は再手術時の血厷拉よび脳循環 monitoring として测定された镇静脈酸素飽和度 $\left(\mathrm{SjO}_{2}\right) \cdot$ spinal CSF pressure の各経時変化である。血流再開による血圧 と $\mathrm{SjO}_{2}$ の変化に 致したspinal CSF pressureの上昇が観 察された。再手術から5年後 syncope が頻発するようにな つたさいに施行した血管撮影では 2 度目のバイパスも閉塞 していたため，人工血管を用いて体外循環下に上行動脤一 

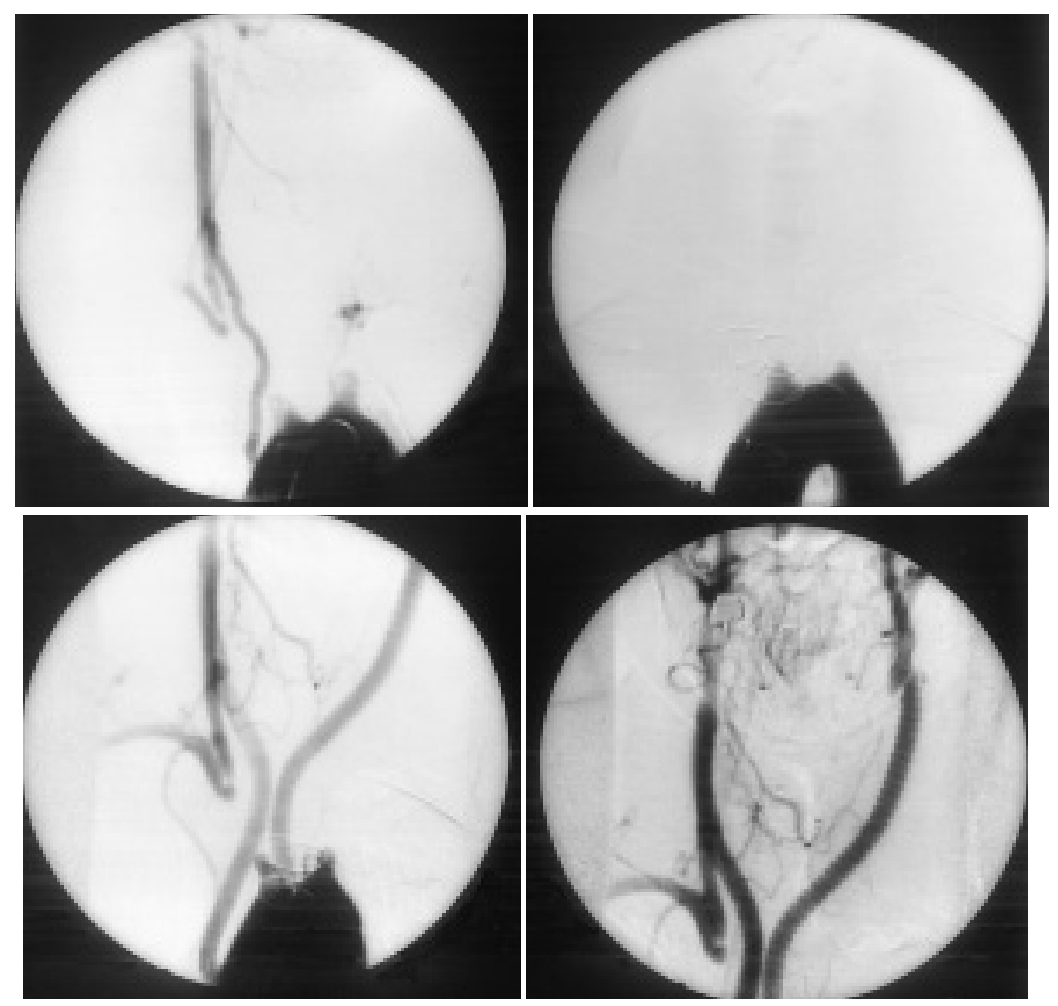

\begin{tabular}{l|l} 
A & B \\
\hline C & D
\end{tabular}

Fig. 4 Aortography of Case 8
A: Aortography was carried out 20 days after the first operation. Ascending aorta to rt. common carotid artery bypass with saphenous vein graft was performed.
B: Delayed occlusion was confirmed 5 years after the second opera- tion.
C, D: Aortography after the third operation. Ascending aorta to bil. common carotid artery bypass with synthetic graft was performed.

两側総钼動脈バイパスが実施された（Fig. 4C，D）。再手術 および 3 度目の術後には数П持続する頭痛・意識障害が出 現した。また 3 度目の術後心機能は正常化していたが 2 非 目に突然 cardiac arrestが出現し 1 度は蘇生できたものの 10 П後に死亡した。剖検の承諾は得られず，心合併症の 原因は確定できなかった。

その他の全身合併症として術後誤嚥性肺炎が 1 例 (Case 1)に認められた。

血行再建術の治療結果としては, 2 例が術後に死亡して おり mortalityは12.5\%であった。死因はCase 1 における 誤嚥性肺炎とCase 8に抢ける心不全である。臨床症状の 改善は，16手術例中 13 例で認められた。

\section{考察}

高安動脈炎は非特異性炎症のために，大動脈执よびその 主要分枝に閉塞性病変を生じる疾患で, 女性が 89-97\% と その大半を占め, 年齢では25歳を平均に比較的若年層に みられる ${ }^{2>5>6) 8>9>11 〉 16\rangle}$.今回対象となった症例は, 脳神

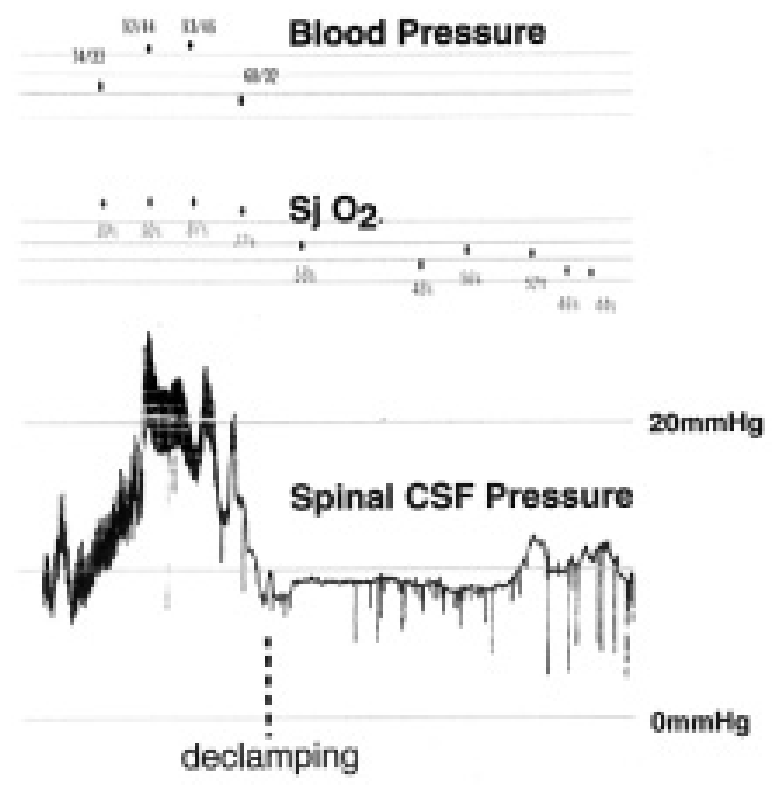

Fig. 5 Intraoperative monitoring of the second operation in Case 8. Blood pressure, $\mathrm{SiO}_{2}$ and spinal CSF pressure rose concurrently just after declamping. 
経外科に扔いて治療された患者であり，すべて brachiocephalic arteriesの狭窄あるいは閉塞を伴っていた，その ような高安動脈炎患者に対してこれまでさまざまな血行再 建術が報告されているが14)15)，その治療方針は主に臨床 症状と血管撮影所見を基に決定されている。

今回われわれは治療経過を検討するにあたり，血管撮影 に加え $\mathrm{CBF}$ 検査も考慮したうえで高安動脈炎患者を 3 グ ループに分類した (Table 2).

CBF 検査の結果ではGroup 3 に含まれる患者は extrac ranial arteries が・部閉塞しているにもかかわらず, 明らかな異常が認められなかった。これらの患者で $\mathrm{CBF}$ 低下をきたさなかったのはWillis 輸を介した頭蓋内側副血 行が十分に発達していたためと考元られる。今回の retrospective studyより Group 3 患者は, retinal hypoperfu-

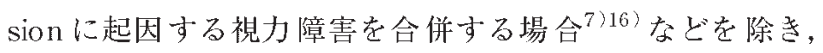
CBF 増加を目的とした血行再建術の適応外であると思わ れた。

Group 2 患者の多くは・側半球の脳虚血症状を呈してい た。これらの患者では extracranial arteriesの一部は patentであるにもかかわらず，CBF 検査の結果は脳虚血 症状に・致した hemispheric hypoperfusionを示した。こ れらの事実より Group 2 患者は脳血流を維持しうるに足り るWillis 輪を介した頭蓋内側副血行を備えていないものと 考えられた。

Group 1 患者の脳虚血症状はその重症度に扔いて他の group と大きく異なっていた.Group 1 患者は健常人では 問題とならない程度の血圧低下でも syncopal attackをき たしたが，それは長期に及ぶ広範な脳血流低下のために脳 血流自動詷節能が障害されていたためと考えられる。術後 hyperperfusion synd romeによると思われる高度の頭痛 · 意識障害といった症状が Group 1 患者 4 例中 2 例に出現し た。術前に hypoperfusionのため最大限に拡張した脳血管 では㑉節機構は障害されて扔り ${ }^{13)}$, その条件下での血行 再建に上る急激な血流增加が $\mathrm{CBF}$ 調節の破綻を招き， hyperperfusion syndromeをきたしたものと考えられる。

hyperperfusion syndromeは，たとえばCEA術後の $12 \%$ 程度に発生するという報告もあり ${ }^{12)}$, 血行再建術の 周術期管理に扔いて，その monitoring と管理をいかに行 うかは重要な課題の.つである. Group 1 患者のように術 前の CBF 低下が高度であるほど術後hyperperfusion を招 く危険性は高くなるといえる. 最近の 3 手術例に扔いて従 来より脳循環 monitoring として利用されている transcranial doppler ( TCD) や钼静脈酸素飽和度 $\left(\mathrm{SjO}_{2}\right)^{17}$ に加えて spinal CSF pressure の経時的 monitoringが行われた(Fig. 5). 血流再開後 TCD P $\mathrm{SjO}_{2}$ と同期して spinal CSF pressure の值も上昇して扔り,これらの結果は, 血行再建に
よる脳血流と代謝の変化を鋭敏に反映しているものと思わ れる。 spinal CSF pressureの測定は手技も簡便であり hyperperfusion を予測するための monitoring として有用 であると思われる。実際にCase 4 と8においては術後頭 痛や軽度の意識障害など hyperperfusion syndromeによ ると思われる症状が出現したが頭蓋内出血などの重篤な合 併症には至らなかった。術前の CBF 検査や術中の monitoringによる hyperperfusion 出現の予測と, 術後早期か らの induced hypotension - barbiturate therapyといった 処置が功を奏したものと考えられた。術後の hyperperfu一 sion出現をいかに予測するかという点で, CBF 検査とそ れに基づく分類は非常に有効な手段と考えられ，特に Group 1 症例は, high risk groupであるといえる.

術後早期の全身合併症として2例に扔いて(Case 8 and 9)心機能不全を経験した。高安動脈炎に合併する心疾患 の原因として文献上いくつかの報告があり278111)，腎血管 性高血圧に由来する高血圧性心不全 ${ }^{5\rangle} \cdot$ 大動脈弁閉鎖不全 $(\mathrm{AR})^{5) 10}$ ・㝴動脈も炎症に巻き込まれた場合の虚血性心 疾患 ${ }^{10)}$ な゙は晾療に当たって常に念頭に扔く必要がある。 われわれの 2 例の場合, 術前の負荷心電汹 T1 シンチグラフィーのいずれの心機能検査でも異常が認 められなかった。したがって，心不全の原因としては潜在 した高血圧性心不全が術後急激に悪化したことである可能 性が高いと思われる。今後の対策として術後の厳重な血圧 管理があげられる。方で, 病理学的に炎症は中膜から始 まり進行すると内膜・外膜へと広範に波及しうる ら, 心不全の原因の一つとして, 術後一時的に炎症が進行 し血管周辺の神経も巻き込まれた結果としての自律神経の 極端な異常も考えられる。対策としては術後頻回の検査に よる炎症状態の把握と十分な抗炎症療法が重要と思われる 4). 高安動脈炎患者の外科治療に扔いては, 予測困難な心 合併症の可能性も念頭に㧈くべきである。

\section{結＼cjkstart論}

高安動脈炎患者に対する血行再建術後の hyperperfu一 sion syndromeを予測するうえで, 術中の経時的脳循環 monitoringに加えて術前の CBF 検查は非常に有効であ る. 血行再建術の必要性が高い患者ほど術後hyperperfu一 sion syndromeを抬く危険性が高く術後早期からの適切 な管理が必要である。術後管理に扔いて, 予測困難な心合 併症の可能性も念頭に置く必要がある。

\section{文献}

1) Bernstein $M$, Fleming JFR, Deck JHN: Cerebral hyperperfusion after carotid endarterectomy: a cause of cerebral hemorrhage. Neurosurgery 15: 50, 1984

2) Hashimoto Y, Oniki T, Aerbajinai W, et al: Aortic regur- 
gitation in patients with Takayasu arteritis: assessment by coloar Doppler echocardiography. Heart vessels Suppl 7: 111-115, 1992

3) Hotchi M: Pathological studies on Takayasu arteritis. Heart vessels Suppl 7: 11-17, 1992

4) Ishikawa K, Yonekawa Y: Regression of carotid stenosis after corticosteroid therapy in occlusive thromboaortopathy (Takayasu's disease). Stroke 18: 677-679, 1987

5) Kerr GS, Hall ahan CW, Giordano J, et al: Takayasu arteritis. Ann Intern Med 120: 919-929, 1994

6) Koide K: Takayasu arteritis in Japan. Heart vessels Suppl 7: 48-54, 1992

7) Lewis JR, Glaser JS, Schatz NJ, et al: Pulseless (Takayasu) disease with ophthalmic manifestations. J Clin Neuro-ophthalmol 13(4): 242-249, 1993

8) Matsubara O, Kuwata T, Nemoto T, et al: Coronary artery lesions in Takayasu arteritis: pathological considerations. Heart vessels Suppl 7: 26-31, 1992

9) Matsubara O, Yoshimura N, Tamura A, et al: Pathological features of the pulmonary artery in Takayasu arteritis. Heart vessels Suppl 7: 18-25, 1992

10) Nagata S: Persent state of autopsy cases of Takayasu's arteritis (aortitis syndrome) in Japan. Myakkangaku 30:
1303-1308, 1990

11) Nishimura $T$, Uehara $T$, Hay ashida $K$, et al : Coronary arterial involvement in aortitis syndrome: assessment by exercise thallium scintigraphy. Heart vessels Suppl 7: 106 110, 1992

12) Piepgras DG, Morgan MK, Sundt TM, et al: Intracerebral hemorrhage after carotid endarterectomy. J Neu rosurg 68: 532,1988

13) Powers AD, Smith RR: Hyperperfusion syndrome after carotid endarterectomy: a transcranial doppler evaluation. Neurosurgery 26: 56, 1990

14) Tada $Y$, Sato O, Ohshima A, et al: Surgical treatment of Takyasu arteritis Heart vessels Suppl 7: 159-167, 1992

15) Taguchi J, Y amada K, Miyamoto Y, et al: By pass surgery for aor titis syndrome: aor tocarotid bypass with saphenous vein graft. Surg Neurol 37: 300-306, 1992

16) Uyama M: A study on pathogeneis of fundic lesions in the pulseless disease. Report of the Research Committee on Aortitis Syndrome, 1973, pp43-46

17) 山田真理, 川口昌彦, 古家 仁, ほ办：大動脈炎症候群に 対方る顽動脈再建于術時の脳循環モニタ一。麻酔 $40(10)$ : $1546^{-1550,} 1991$ 